\title{
Molecular Docking Senyawa Gingerol dan Zingiberol pada Tanaman Jahe sebagai Penanganan COVID-19
}

\author{
Belinda D. P. M. Ratu, ${ }^{1}$ Widdhi Bodhi, ${ }^{2}$ Fona Budiarso, ${ }^{2}$ Billy J. Kepel, ${ }^{2}$ Fatimawali, ${ }^{2}$ \\ Aaltje Manampiring ${ }^{2}$
}

\author{
${ }^{1}$ Program Studi Pendidikan Dokter Fakultas Kedokteran Universitas Sam Ratulangi \\ Manado, Sulawesi Utara, Indonesia \\ ${ }^{2}$ Bagian Kimia Fakultas Kedokteran Universitas Sam Ratulangi Manado, Sulawesi Utara, \\ Indonesia \\ Email: putribelinda65@gmail.com
}

\begin{abstract}
COVID-19 is a new disease. Many people feel the impact of this disease. There is no definite cure for COVID-19, so many people use traditional medicine to ward off COVID19 , including ginger. This study aims to determine whether there is an interaction between compounds in ginger (gingerol and zingiberol) and the COVID-19's main protease (6LU7). This study uses a molecular docking method using 4 main applications, namely Autodock Tools, Autodock Vina, Biovia Discovery Studio 2020, and Open Babel GUI. The samples used were gingerol and zingiberol compounds in ginger plants downloaded from Pubchem. The data used in this study used Mendeley, Clinical Key, and PubMed database. The study showed that almost all of the amino acid residues in the gingerol compound acted on the 6LU7 active site, whereas the zingiberol did not. The results of the binding affinity of ginger compounds, both gingerol and zingiberol, do not exceed the binding affinity of remdesivir, a drug that is widely researched as a COVID-19 handling drug. In conclusion, gingerol and zingiberol compounds in ginger can't be considered as COVID-19's treatment.
\end{abstract}

Keywords: molecular docking, gingerol, zingiberol

\begin{abstract}
Abstrak: COVID-19 merupakan sebuah penyakit yang baru. Banyak masyarakat yang merasakan dampak dari penyakit ini. Belum ada pengobatan pasti untuk menyembuhkan COVID-19, sehingga banyak masyarakat yang menggunakan pengobatan tradisional untuk menangkal COVID-19, termasuk jahe. Penelitian ini bertujuan untuk mengetahui apakah ada interaksi antara senyawa pada jahe (gingerol dan zingiberol) dengan main protease COVID-19 (6LU7). Penelitian ini menggunakan metode molecular docking dengan menggunakan 4 aplikasi utama, yaitu Autodock Tools, Autodock Vina, Biovia Discovery Studio 2020, dan Open Babel GUI. Sampel yang digunakan yaitu senyawa gingerol dan zingiberol pada tanaman jahe yang diunduh di Pubchem. Data yang digunakan dalam penelitian ini menggunakan database Mendeley, Clinical Key, dan PubMed. Penelitian menunjukkan bahwa hampir semua residu asam amino pada senyawa gingerol bekerja pada sisi aktif 6LU7, sedangkan tidak demikian pada zingiberol. Hasil binding affinity senyawa jahe, baik gingerol maupun zingiberol tidak melebihi binding affinity remdesivir, obat yang banyak diteliti sebagai obat penanganan COVID-19. Sebagai simpulan, senyawa gingerol dan zingiberol pada tanaman jahe tidak dapat dipertimbangkan sebagai penanganan COVID-19
\end{abstract}

Kata Kunci: molecular docking, gingerol, zingiberol

\section{PENDAHULUAN}

Coronavirus Disease 2019 atau yang lebih sering dikenal dengan sebutan COVID-19, merupakan hal yang baru dan menggemparkan dunia, khususnya di
Indonesia. COVID-19 pertama kali terjadi di Kota Wuhan, Cina. ${ }^{1}$ Sampai saat ini, belum ditemukan adanya penanganan pasti COVID-19. 
Masyarakat Indonesia, khususnya masyarakat yang ada di daerah memercayai khasiat dari pengobatan tradisional dimana menggunakan tanaman obat seperti jahe, kunyit, serai, dan lainnya. Pada masa pandemik COVID-19 ini, banyak masyarakat yang memanfaatkan tanaman jahe sebagai penangkal COVID-19. Selama ini jahe digunakan sebagai pengobatan tradisional untuk berbagai macam penyakit. $^{2}$ Jahe juga dipercaya sebagai antioksidan. $^{3} \quad$ Masyarakat biasa mengonsumsi jahe dengan cara merebus dengan air maupun dibuat sebagai minuman yang dicampurkan dengan gula merah. Oleh karena itu, banyak masyarakat yang percaya bahwa dengan mengonsumsi jahe maka dapat mencegah terpapar COVID-19.

Berdasarkan latar belakang tersebut, penulis tertarik untuk melakukan penelitian senyawa dalam jahe (gingerol dan zingiberol) terhadap hubungannya dengan main protease SARS Cov-2 (COVID-19).

\section{METODE PENELITIAN}

Penelitian ini dilakukan pada bulan September-Desember 2020 di Fakultas Kedokteran Universitas Sam Ratulangi. Jenin penelitian yang digunakan adalah metode in silico. Sampel yang digunakan yaitu senyawa gingerol dan zingiberol pada jahe. Main protease COVID-19 yang digunakan yaitu 6LU7.

Dengan penambatan gingerol dan zingiberol pada 6LU7 (main protease COVID-19) dalam aplikasi Biovia Discovery Studio Visualisasi diharapkan dapat terlihat berapa besar kemungkinan gingerol dan zingiberol sebagai antiinhibitor COVID-19.

Alat yang digunakan adalah perangkat keras Laptop Asus series E402Y dengan spesifikasi Processor AMD Dual Core E27015 APU with AMD Radeon R2 Graphics 1,50 GHz, RAM 4.00 GB ( dengan 0,57 GB terpakai), dengan hard disk drive (HDD) 1 TB dan perangkat lunak yaitu aplikasi Autodock Tools, Autodock Vina, Biovia Discovery Studio 2020, dan Open Babel GUI.
Bahan yang digunakan adalah struktur 3D 6LU7 dengan PDB Format diunduh di https://www.rcsb.org/ yang merupakan main protease dari COVID-19 dan struktur 3D ligan senyawa gingerol dan zingiberol pada tanaman jahe yang diunduh di https://pubchem.ncbi.nlm.nih.gov/.

Langkah pertama untuk prosedur penelitian adalah persiapan ligan (gingerol dan zingiberol) yang akan diubah formatnya dari .sdf menjadi .pdb pada aplikasi Open Babel GUI. Selanjutnya untuk persiapan reseptor (6LU7), buka aplikasi Biovia Discovery untuk membersihkan molekul air dan native ligand pada reseptor untuk mendapatkan reseptor yang murni. Setelah ligan dan reseptor telah disiapkan, buka reseptor pada aplikasi Autodock Tools untuk menambahkan atom hidrogen dengan tujuan menyamakan suhu komputasi reseptor dan buka ligan juga untuk mengatur number of torsions kemudian di save. Langkah selanjutnya adalah proses penambatan. Untuk mengetahui tempat penambatan ligan pada reseptor, buka situs Computed Atlas of Surface Topography of Protein untuk melihat binding site yang aktif pada reseptor kemudian docking dengan metode blind docking. Catat semua penomoran dan format di Notepad. Setelah itu, gabungkan semua file beserta aplikasi Autodock Vina (autodock vina, vina_split, dan vina_license) dalam satu folder kemudian masukkan rumus untuk perhitungan di Command Prompt, sebagai berikut:

D: $>$ cd nama file $>$

vina -config file notepad.txt - log log.txt

vina_split -input out.pdbqt

Setelah itu lihat nilai binding affinity yang paling minus karena semakin kecil nilai binding affinity, kemampuan pengikatan antara ligan yang digunakan dan reseptor semakin kuat. ${ }^{4}$ Langkah terakhir adalah visualisasi reseptor dan ligan pada aplikasi Biovia Discovery, baik bentuk 2D maupun 3D, untuk melihat ikatan-ikatan dan residu asam amino yang terbentuk. 


\section{HASIL PENELITIAN}

Hasil penelitian menunjukkan hasil binding affinity (Tabel 1) dan juga visualisasi, baik 2D (Gambar 1, Gambar 2) maupun 3D (Gambar 3, Gambar 4). Sebelum melakukan penambatan, atur number of torsion terlebih dahulu. Pada gingerol menggunakan number of torsion 12, sedangkan zingiberol 10. Tempat penambatan yang digunakan pada grid box yaitu center $\mathrm{x}=-11.500, \mathrm{y}=17.000, \mathrm{z}=$ 68.000 , size $x, y, z=25$. Nilai keakuratan (exhaustiveness) yang digunakan adalah 8 .

Tabel 1. Binding affinity senyawa gingerol dan zingiberol terhadap 6LU7

\begin{tabular}{ccc}
\hline Senyawa & Reseptor & $\begin{array}{c}\text { Binding affinity } \\
\text { (kkal/mol) }\end{array}$ \\
\hline Gingerol & $6 \mathrm{LU} 7$ & $-5,7$ \\
Zingiberol & $6 \mathrm{LU} 7$ & $-5,7$ \\
\hline
\end{tabular}

Gambar 1 memperlihatkan hasil visualisasi bentuk 2D dari docking senyawa gingerol dengan 6LU7 didapatkan beberapa interaksi seperti ikatan ikatan van der Waals, ikatan hidrogen konvensional, ikatan karbon hidrogen, ikatan pi-alkil, dan alkil.

Gambar 2 memperlihatkan hasil visualisasi bentuk 2D dari docking senyawa zingiberol dengan 6LU7 didapatkan beberapa interaksi seperti ikatan ikatan van der Waals, ikatan hidrogen konvensional, unfavorable acceptor-acceptor, pi-sigma, pi-sulfur, ikatan pi-alkil, dan alkil.

\section{BAHASAN}

Dalam menentukan ligan, sebaiknya harus memenuhi aturan yang dirumuskan oleh Christoper A. Lipinski, sesuai dengan namanya yaitu Aturan Lima Lipinski atau sering dikenal dengan sebutan Rules of Five (RO5). ${ }^{5}$ Aturan Lipinski antara lain: berat molekul $<500, \log \mathrm{P}<5$, ikatan hidrogen donor $<5$, dan ikatan hidrogen aseptor $<10{ }^{5}$ Pemenuhan syarat RO5 bermaksud untuk membantu menambah tingkat keberhasilan percobaan. ${ }^{6}$ (Tabel 2)

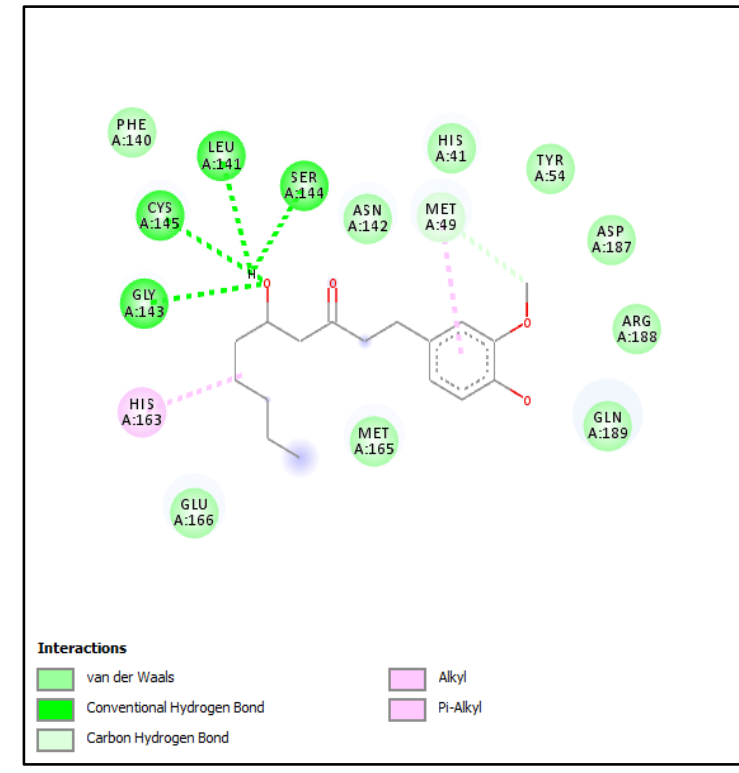

Gambar 1. Visualisasi 2D Gingerol

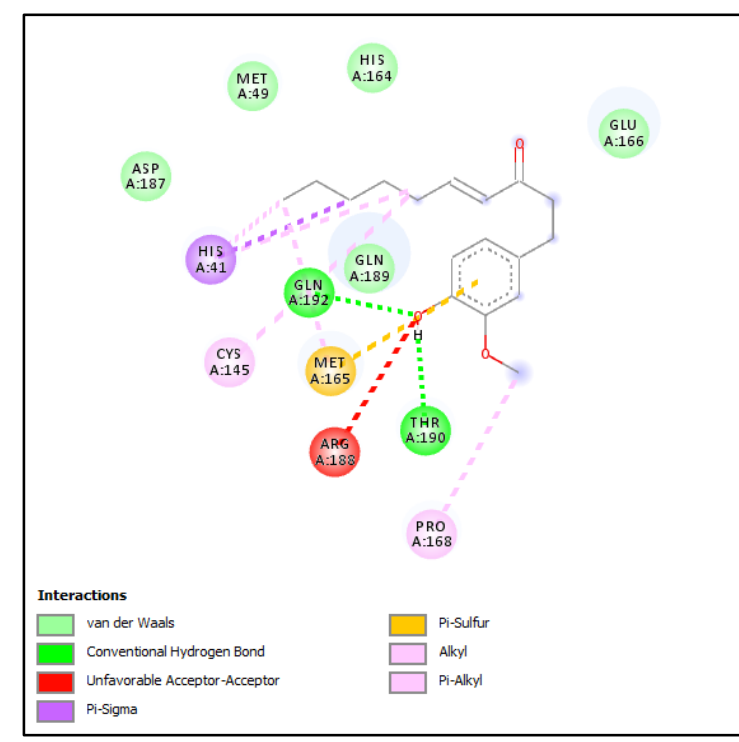

Gambar 2. Visualisasi 2D Zingiberol

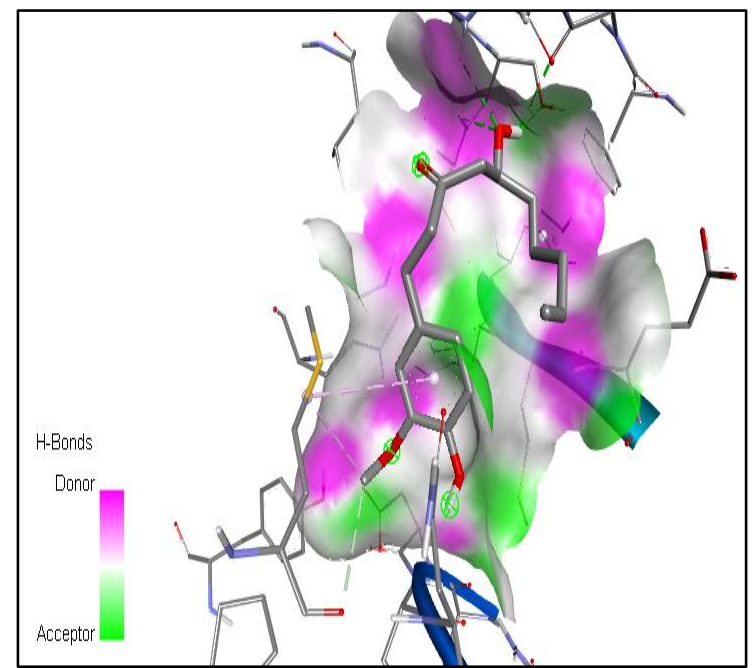

Gambar 3. Visualisasi 3D Gingerol 


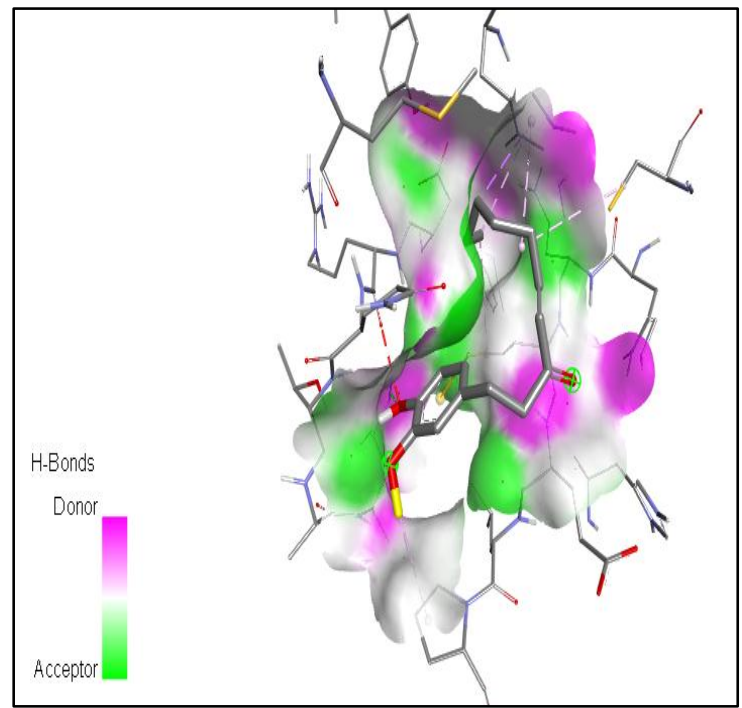

Gambar 4. Visualisasi 3D Zingiberol

Berdasarkan hasil molecular docking senyawa gingerol dan zingiberol terhadap 6LU7 didapatkan ikatan van der Waals dan ikatan hidrogen yang terdapat dikedua hasil docking. Kedua ikatan tersebut merupakan peran penting dalam hasil docking. Gambar 1 memperlihatkan ikatan van der Waals pada senyawa gingerol terbentuk pada residu asam amino HIS41, TYR54, PHE140, ASN142, MET165, GLU166, ASP187, ARG188 dan GLN189 dan juga ada ikatan hidrogen yang terbentuk pada residu asam amino LEU141, GLY143, SER144, dan CYS145. Gambar 2 memperlihatkan ikatan van der Waals pada senyawa zingiberol terbentuk pada residu asam amino MET49, HIS164, GLU166, ASP187, dan GLN189 dan juga ikatan hidrogen terbentuk pada residu asam amino THR190 dan GLU192.

Berdasarkan Computed Atlas of Surface Topography of Proteins, diketahui sisi aktif dari 6LU7 berada pada residu asam amino yaitu THR24, THR25, THR26, LEU27, HIS41, THR45, SER46, MET49, PHE140,
LEU141, ASN142, GLY143, SER144, CYS145, HIS163, MET165, MET166, dan HIS172. Dari hasil penelitian ini, didapatkan ikatan van der Waals senyawa gingerol yang bekerja pada sisi aktif 6LU7 terdapat pada residu asam amino HIS41, PHE140, ASN142, MET165, dan GLU166, sedangkan pada senyawa zingiberol terdapat pada residu asam amino MET49 dan GLU166. Ikatan hidrogen senyawa gingerol yang bekerja pada sisi aktif 6LU7 terdapat pada residu asam amino LEU141, GLY143, SER144, dan CYS145, sedangkan pada senyawa zingiberol tidak ada. Dari hasil tersebut, didapatkan bahwa hampir semua residu asam amino pada senyawa gingerol baik ikatan van der Waals maupun ikatan hidrogen, bekerja pada sisi aktif 6LU7. Namun, tidak demikian pada senyawa zingiberol, hanya ikatan van der Waals saja yang sebagian residu asam aminonya bekerja pada sisi aktif.

Pada penelitian ini, menggunakan kontrol positif yaitu obat remdesivir. Remdesivir adalah salah satu obat yang berpotensi untuk membloking infeksi virus. ${ }^{7}$ Cara kerja remdesivir yaitu dengan menginhibisi viral melalui penghentian transkripsi RNA. ${ }^{8}$ Hasil binding affinity remdesivir terhadap 6LU7 adalah -7.3 $\mathrm{kkal} / \mathrm{mol}$.

Dari hasil penelitian, didapatkan bahwa binding affinity senyawa pada jahe yang diteliti, baik gingerol maupun zingiberol tidak melebihi bahkan menyamai binding affinity dari Remdesivir, yang artinya senyawa jahe baik gingerol maupun zingiberol, belum bisa dipertimbangkan sebagai tanaman penanganan COVID-19.

Tabel 2. Pemenuhan Aturan Lipinski Ligan

\begin{tabular}{cccccc}
\hline Senyawa & $\begin{array}{c}\text { Berat } \\
\text { Molekul }\end{array}$ & LogP & $\begin{array}{c}\text { Ikatan hidrogen } \\
\text { donor }\end{array}$ & $\begin{array}{c}\text { Ikatan hidrogen } \\
\text { aseptor }\end{array}$ & $\begin{array}{c}\text { Pemenuhan } \\
\text { RO5 }\end{array}$ \\
\hline Gingerol & 294.4 & 2.5 & 2 & 4 & Ya \\
Zingiberol & 222.37 & 3.7 & 1 & 1 & Ya \\
\hline
\end{tabular}




\section{SIMPULAN}

Binding affinity dari senyawa pada tanaman jahe, baik gingerol maupun zingiberol tidak melebihi bahkan menyamai binding affinity dari Remdesivir sehingga senyawa gingerol dan zingiberol pada tanaman jahe belum bisa dipertimbangkan sebagai penanganan COVID-19.

\section{Konflik Kepentingan}

Penulis menyatakan tidak terdapat konflik kepentingan dalam studi ini.

\section{DAFTAR PUSTAKA}

1. Kementerian Kesehatan Republik Indonesia. Pedoman Kesiapsiagaan Menghadapi Coronavirus Disease (COVID-19). Direkorat Jenderal Pencegah dan Pengendali Penyakit. Published online 2020.

2. Aryanta IWR. Manfaat Jahe Untuk Kesehatan. Widya Kesehatan. 2019;1(2):39-43.

3. Assa JR, Saragih J, Langi TM. Aktivitas Antioksidan Ekstrak Jahe Merah (Zingiber officinale var. rubrum) Menghambat Oksidasi Minyak Kacang Tanah (Arachis hypogaea L.). Cocos 2015;6(15):44-51.

4. Masula AF, Puspitasari D, Supriatin SWE, Ummah K, Rokhmatin D,Mubarrok, et al. Docking Molekuler Senyawa Metabolit Sekunder Lantana camara sebagai Antiinflamasi terhadap Enzim COX-1. Jurnal Biota 2018;4(2): $79-83$
5. Tallei TE, Tumilaar SG, Niode NJ, Fatimawali, Kepel BJ, Idroes R, et al. Potential of Plant Bioactive Compounds as SARS-CoV-2 Main Protease $\left(\mathrm{M}^{\mathrm{pro}}\right)$ and Spike (S) Glycoprotein Inhibitors: A Molecular Docking Study. Scientifica 2020; Article ID 6307457:1-18. Available from: https://www.hindawi.com/journals /scientifica/2020/6307457/

6. Khaerunnisa S, Kurniawan H, Awaluddin R, Suhartati $\mathrm{S}$, Soetjipto S. Potential Inhibitor of COVID-19 Main Protease ( $\mathrm{M}^{\mathrm{pro}}$ ) from Several Medicinal Plant Compounds by Molecular Docking Study. Preprint from: Preprints.org,13 Mar 2020.

Available from: https://doi.org/ 10.20944/preprints202003.0226.v1

7. Naik VR, Munikumar M, Ramakrishna U, Srujana M, Goudar G, Naresh $\mathrm{P}$, et al. Remdesivir (GS-5734) as a therapeutic option of 2019nCOV main protease - in silico approach. J Biomol Struct Dyn. Published online 2020. Available from: https://doi.org/10.1080/ 07391102.2020.1781694.

8. Wadhwa P. Molecular Docking Study of Novel COVID-19 Protease with Current Clinical Management Agents. Asian J Pharm Clin Res. 2020;13(9):37-9. Available from: https://doi.org/10.22159/ajpcr.202 0.v13i9.38501. 